\title{
Effect of Huagantongluofang, a Chinese Traditional Medicine, in Hepatic Fibrogenesis in a Mouse Model of Biliary Cirrhosis
}

\author{
Ji Xuan ${ }^{a}$ Wei Wen ${ }^{a}$ Yong Wang ${ }^{b}$ Feng Wang ${ }^{c}$ Hua-bing Xua Mei Shao \\ Ya Yang a Yao-zhou Tian ${ }^{d}$ \\ ${ }^{a}$ Department of Gastroenterology, ${ }^{b}$ Administration and ${ }^{\mathrm{G}}$ General Surgery, Bayi Hospitial Affiliated \\ Nanjing University of Chinese Medicine, Nanjing, China; ${ }^{d}$ Department of Gastroenterology, Affiliated \\ Hospital of Integration of Chinese and Western Medicine, Nanjing University of Chinese Medicine, \\ Jiangsu Province Hospital on Integration of Chinese and Western Medicine, Nanjing, China
}

\section{Key Words}

Biliary cirrhosis $(B C) \cdot$ Hepatic inflammation • Hepatic fibrosis • HuaGanTongLuoFang

\begin{abstract}
Background: Biliary cirrhosis (BC) is a chronic cholestatic liver disease, in which hepatic fibrosis is an early symptom. This study aimed to identify the biological function and the therapeutic effect of a Chinese traditional medicine, HuaGanTongLuoFang (HGTLF), in a mouse model of BC. Methods: The mice $(n=72)$ were randomly divided into a sham group $(n=12)$ and BC group $(n=60)$. The animals in the BC group were then randomly divided into five groups $(n=$ 12 in each) and treated with three different doses of HGTLF, ureodeoxycholic acid (UDCA), or normal saline (the model group). Four weeks later, serum and liver tissues were obtained from all the animals for analyses. Hematoxylin and eosin (H\&E) staining was used to quantify the hepatic morphology, while real-time PCR and Enzyme-linked immunosorbent assay (ELISA) were used to determine the level of hepatic fibrosis-related genes. Results: Compared with the model group, all three doses of HGTLF improved hepatic function, as well as reducing inflammation and fibrogenesis. The best therapeutic effect was observed in the high-dose HGTLF group. Furthermore, HGTLF contributed to down-regulation of hepatic fibrosis-related genes (platelet-derived growth factor [PDGF], transforming growth factor- $\beta$ [TGF- $\beta$ ], p38, nuclear factor- $\mathrm{\kappa B}[\mathrm{NF}-\kappa \mathrm{B}]$, intercellular adhesion molecular-1 [ICAM-1], and tissue inhibitor of metalloproteinase-1 [TIMP-1]). Conclusion: The data suggested that HGTLF effectively improved liver function and the morphology of the liver tissue in a mouse model of BC, possibly via suppression of hepatic fibrosis-related signals.
\end{abstract}




\section{Cellular Physiology Cell Physiol Biochem 2017;44:368-376 \begin{tabular}{l|l|l} 
and Biochemistry & DOI: 10.1159/000484908 & (c) 2017 The Author(s). Published by S. Karger AG, Basel \\
www.karger.com/cpb
\end{tabular} Xuan et al.: Effect of HGTLF on Biliary Cirrhosis}

\section{Introduction}

Biliary cirrhosis (BC) is widely considered as an autoimmune disease, which appears to develop as a result of bile duct obstruction and cholestasis. On the basis of predisposing factors, $\mathrm{BC}$ can be classified into primary $\mathrm{BC}$ or secondary $\mathrm{BC}$. The progression of cirrhosis to hepatic failure is a serious threat to human health. A previous study reported that BC patients was common in western countries, including Europe and the U.S [1].. The prevalence of BC in China is increasing. At present, the major therapeutic method for $\mathrm{BC}$ is pharmacological (i.e., anti-fibrosis, anti-inflammation, and immunosuppressive drugs). Previous studies pointed to several factors that might be closely associated with BC [2]. However, the pathogenesis of $\mathrm{BC}$ is not fully understood so far [2]. Consequently, no effective anti-BC drug has been developed.

Ursodeoxy-cholic acid (UDCA) is a primary drug used to treat BC. However, the results of UDCA treatment are unsatisfactory in $30-40 \%$ of patients [1]. Given the lack of therapeutic efficacy of UDCA, the potential of Chinese traditional medicines in the treatment of BC has attracted interest. For example, Wang et al. demonstrated that aqueous extracts of Yin-ChenHao-Tang, a traditional Chinese drug, in a 1:2:3 ratio (Rheum rhabarbarum [rhubarb], Gardenia sp., and Artemisia capillaris, respectively) prevented biliary epithelial cell proliferation and activation, thereby inhibiting BC [3]. Yin-Chen-Hao-Tang also exerted anti-hepatic fibrosis in effects in rats following bile duct ligation [4]. Another traditional medicine, Inchin-ko-to, which consists of three herbs (Artemisiar capillaris spica, Gardenia fructus, and Rhei rhizome) , ameliorated liver fibrosis in patients with biliary atresia [5].

HuaGanTongLuoFang (HGTLF) is a Chinese medicine derived from Lang qing A ta, a famous traditional Tibetan prescription developed by Professor Yaozhou Tian [6]. The anti$\mathrm{BC}$ effect was demonstrated in primary $\mathrm{BC}$ [7]. However, the mechanism underlying this process has not been well defined.

Hepatic fibrosis, which refers to abnormal hyperplasia of hepatic connective tissue, is the first stage in the progression to $\mathrm{BC}[8,9]$. Therefore, focusing on inhibition of liver fibrosis is considered an effective approach in $\mathrm{BC}$ therapy. The activation of hepatic stellate cells and up-regulation of platelet-derived growth factor (PDGF) are important cellular events in hepatic fibrosis. Thus, preventing these events could potentially inhibit liver fibrosis [8]. In addition, the regulation of fibrosis-related inflammatory signaling pathway, such as the nuclear transcription factor kappa B (NF- $\kappa B$ ) pathway, could help to prevent fibrosis [10]. It remains unclear whether HGTLF influences the aforementioned hepatic fibrosis-related events.

In the present study, a mouse model of $\mathrm{BC}$ was established and used to evaluate the therapeutic effects of HGTLF, focusing on its effect on hepatic dysfunction, liver fibrosis, and hepatic inflammation. The potential mechanism by which HGTLF inhibits hepatic fibrosis was also investigated.

\section{Materials and Methods}

\section{Animals grouping and molding}

A total, 72 male mice(weighting $180 \pm 20 \mathrm{~g}$ ) were obtained from Nanjing Qinglongshan animal breeding ground (SCXK2010-0001). The animals were randomly divided into a sham group (n=12) and BC group $(n=60)$. To establish a BC model, the animals were intraperitoneally anesthetized with $10 \%$ Chloral hydrate solution $(300 \mathrm{mg} / \mathrm{kg}$ ) and underwent abdominal surgery along with the abdominal medial line. The choledoch was found and ligatured in proximal hepatic hilar. The Sham animals underwent abdominal surgery and choledocholith was isolated. The surgical incision was then closed. All the mice were injected with penicillin for three day postoperatively and had access to food ad libitum.

Next, based on a drug volume of $10 \mathrm{~mL} / \mathrm{kg}$, the 60 mice in BC group were randomly divided into five groups ( $n=12$ mice in each group): a model group, UDCA group, high-dose HGTLF group, medium-dose HGTLF group, low-dose HGTLF group. Eight days after the surgery, the animals in the drug treatment 


\section{Cellular Physiology Cell Physiol Biochem 2017;44:368-376 \\ \begin{tabular}{l|l|l} 
and Biochemistry 10.1159/000484908 & $\begin{array}{l}\text { C } 2017 \text { The Author(s). Published by S. Karger AG, Basel } \\
\text { www.karger.com/cpb }\end{array}$
\end{tabular} \\ Xuan et al.: Effect of HGTLF on Biliary Cirrhosis}

groups were administered UDCA at a dose of $55 \mathrm{mg} \cdot \mathrm{kg}^{-1} \cdot \mathrm{d}^{-1}$ or HGTLF at doses of $11 \mathrm{~g}^{\mathrm{kg}} \mathrm{kg}^{-1} \cdot \mathrm{d}^{-1}, 5.5 \mathrm{~g} \cdot \mathrm{kg}^{-1} \cdot \mathrm{d}^{-1}$, or $2.75 \mathrm{~g} \cdot \mathrm{kg}^{-1} \cdot \mathrm{d}^{-1}$ by gavage for seven days. The sham and model groups were received an equal volume of normal saline. All animals were sacrificed at $24 \mathrm{~h}$ after the final gavage and serum and liver tissue were obtained for later analyses.

This work was approved by the Ethics Committee of the Nanjing University of Chinese Medicine. All the animal experiments were performed in accordance with established ethical guidelines governing the use of animals.

\section{HGTLF formulation and dosages}

HGTLF granules (1000 g) were synthesized using the conventional herbal preparation technology. The granules consisted of the following: $0.1 \mathrm{~g}$ of calculus bovis factitious, $15 \mathrm{~g}$ of carthami flowers, $15 \mathrm{~g}$ of trogopterus dung, $30 \mathrm{~g}$ of phyllanthus emblica, $15 \mathrm{~g}$ of swertia chirayita, $10 \mathrm{~g}$ of nutmeg, $25 \mathrm{~g}$ of astragalus membranaceus, $10 \mathrm{~g}$ of radix aucklandiae, $15 \mathrm{~g}$ of saxifrage, $10 \mathrm{~g}$ of coriander fruit, $3 \mathrm{~g}$ of agilawood, $20 \mathrm{~g}$ of pomegranate seeds, $8 \mathrm{~g}$ of rhododendron anthopogonoide, $15 \mathrm{~g}$ of fructus malvae vertillatae, and $10 \mathrm{~g}$ of liquorice.

Based on a HGTLF dose of $10 \mathrm{mg}$, taken three times daily for an adult weighing $60 \mathrm{~kg}$, the estimated daily dose for mice was $0.5 \mathrm{~g} \cdot \mathrm{kg}^{-1} \cdot \mathrm{d}^{-1}$. Based on this dose, the low dose of HGTLF was $2.75 \mathrm{~g} \cdot \mathrm{kg}^{-1} \cdot \mathrm{d}^{-1}$, the middle-dose was $5.5 \mathrm{~g} \cdot \mathrm{kg}^{-1} \cdot \mathrm{d}^{-1}$, and the high-dose was $11 \mathrm{~g} \cdot \mathrm{kg}^{-1} \cdot \mathrm{d}^{-1}$. The dose of UDCA used in this study was in accordance with established guidelines.

\section{Blood chemistry analysis}

Serum aspartate aminotransferase (AST), alanine aminotransferase (ALT), total bilirubin (T-BIL), gamma glutamyltranspeptidase (GGT), direct bilirubin (D-BIL), and alkaline phosphatase (ALP) were measured using assay kits (Nanjing Jiancheng Bioengineering Institute, China) and a standard autoanalyzer (OLYMPUS AU5400).

\section{Hematoxylin and eosin (H\&E) staining}

The livers of all the animals were fixed with $4 \%$ paraformaldehyde for $4 \mathrm{~h}$ and then transferred to $70 \%$ ethanol. The tissues were then embedded with paraffin and cut into $4 \mu \mathrm{m}$ slices. The biopsy samples were stained with H\&E and observed by a microscope (Thermo Fisher), with magnification of $20 \times$ (objective lens) and $10 \times$ (eyepiece lens).

\section{Real-time quantitative polymerase chain reaction (RT-qPCR)}

Total RNA was isolated using an RNA easy kit (Qiagen). After quantification, an equal quantity of each sample was reversely transcribed into cDNA using a PrimeScript@ RT Regent Kit (Takara). The qPCR was performed with a SYBR Premix Ex Taq II kit (Takara) on an Applied Biosystems 7000 Fast Real-Time PCR system. The sequence of the primers were as follows: transforming growth factor- $\beta$ (TGF- $\beta$ ): forward primer: 5'-TATAGCAACAATTCCTGGCG-3' and reverse primer: 5'-TGCTGT CACAGGAGCAGTG-3'; p38: forward primer: 5'-TCCAAGGGCTACACCAAATC-3' and reverse primer: 5'-TGTTCCAGGTAAGGGTGAGC-3'; nuclear factor- $\kappa \mathrm{B}(\mathrm{NF}-\kappa \mathrm{B})$ : forward primer: 5'-GAGGTCTCTGGGGGTACAGTC-3' and reverse primer: 5'-GGACAACGCAGTGGAATTTTA-3'; plasma-derived growth factor (PDGF): forward primer: 5'-GGCTCGAAGTCAGATCCAC-3' and reverse primer: 5'-CTTGAC GCTGCTGGTGTTAC-3'. The relative expression levels of these genes were normalized to those of the mice in the model group.

Enzyme-linked immunosorbent assay (ELISA)

The serum levels of intercellular adhesion molecular-1 (ICAM-1) and tissue inhibitor of metalloproteinase-1 (TIMP-1) were detected by ELISA methods according to manufacturers' protocols.

\section{Statistical analysis}

Statistical analysis was performed with ANOVA (one way analysis of variance) using SPSS13.0 software. All data were expressed as means \pm SD. A $P$ value less than 0.05 was considered to denote a statistically significant difference. 


\section{Cellular Physiology Cell Physiol Biochem 2017;44:368-376 \begin{tabular}{l|l} 
DOI: 10.1159/000484908 & $\begin{array}{l}\text { O 2017 The Author(s). Published by S. Karger AG, Basel } \\
\text { www.kargercom/cpb }\end{array}$
\end{tabular} \\ Xuan et al.: Effect of HGTLF on Biliary Cirrhosis}

\section{Results}

\section{The HGTLF treatment improved liver function}

Fig. 1 shows the serum levels of six liver function indexes (ALT, AST, T-BIL, D-BIL, GGT and ALP) in the different HGTLF treatment groups. All six liver function indexes were substantially elevated in the model group, indicating that the BC model was successful. All the low, medium, and high doses of HGTLF significantly reduced the serum levels of these six liver function indexes. Importantly, the therapeutic effect of the high-dose HGTLF treatment was the same as that achieved using UDCA.

\section{HGTLF induced changes in liver histopathology}

The morphological changes in all the groups were shown in Fig. 2. The histopathological analysis of the liver tissue in the sham group featured a hepatic lobule, a normal looking hepatic plate, and polygonous liver cells (Fig. 2A). In contrast, the liver tissue of the model group was infiltrated with inflammatory cells, and the hepatic lobule was split into pseudolobuli by hyperplastic connective tissue (Fig. 2B). The UDCA treatment resulted in no obvious inflammatory cell infiltration, and fiber connective tissue hyperplasia was improved (Fig. 2C). Some inflammatory cells infiltration was observed in the livers of the low-dose HGTLF group, but the treatment alleviated hyperplasia of fiber connective tissue (Fig. 2D). In the medium-dose HGTLF group, both inflammatory cell infiltration and fiber connective tissue hyperplasia were reduced (Fig. 2E). In the high-dose HGTLF group, the morphology of the liver tissue was the same as that in the UDCA group, with no obvious inflammatory cell infiltration or fiber connective tissue hyperplasia (Fig. 2F).

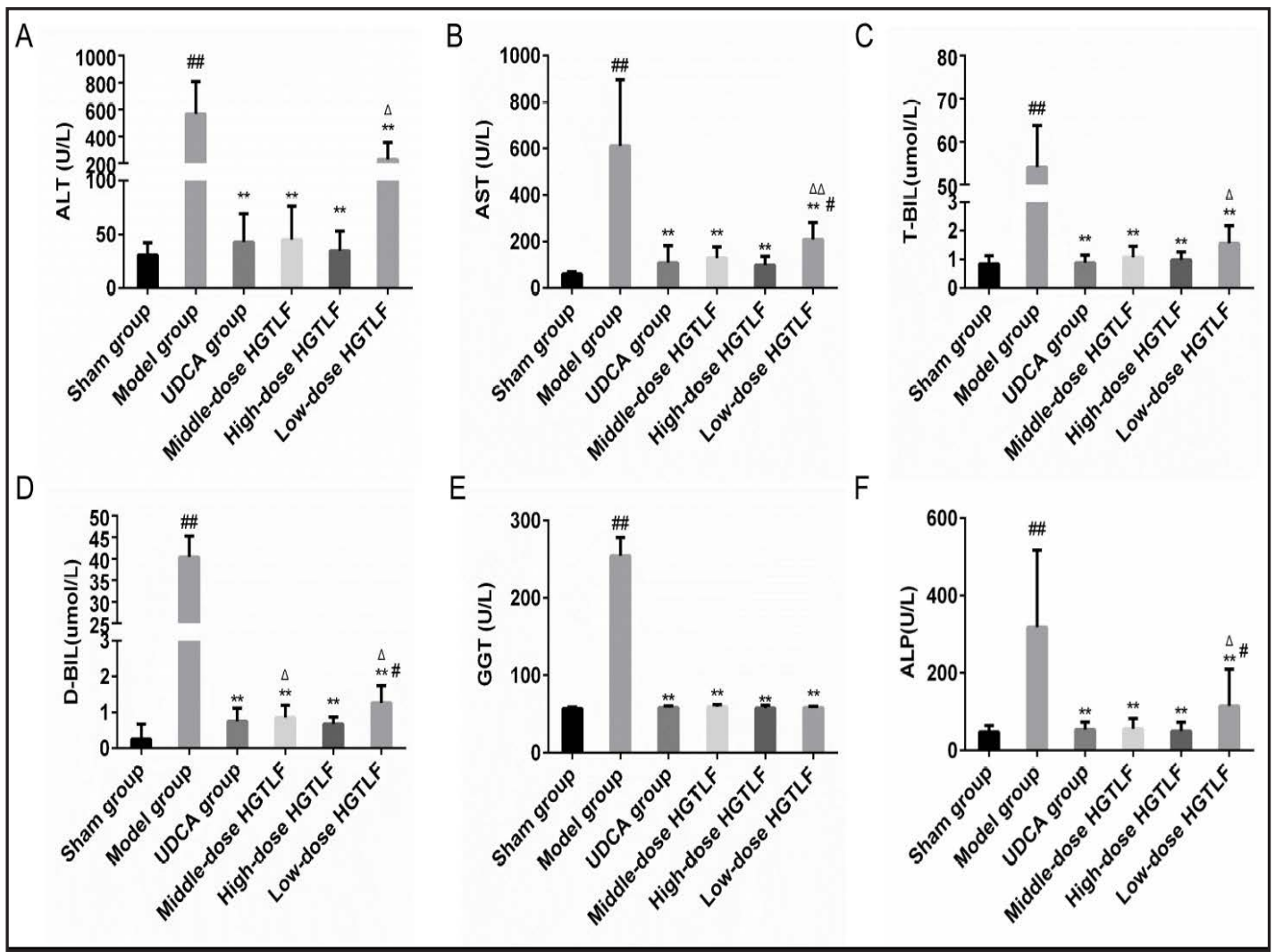

Fig. 1. Serum levels of six liver function indexes in the different treatment groups. (A) ALT, (B) AST, (C) T-BIL, (D) D-BIL, (E) GGT, and (F) ALP. The data are presented as the mean \pm SD. ${ }^{\mathrm{P}}<0.05$ compared with the sham group; ${ }^{*} \mathrm{P}<0.05$ compared with the model group; ${ }^{\triangle} \mathrm{P}<0.05$ compared with the UDCA group. 
Fig. 2. Morphological changes of the liver tissues in the different groups. (A) the sham group, (B) the model group, (C) the UDCA group, (D) the low-dose HGTLF group, (E) the medium-dose HGTLF group, and (F) the high-dose HGTLF group.
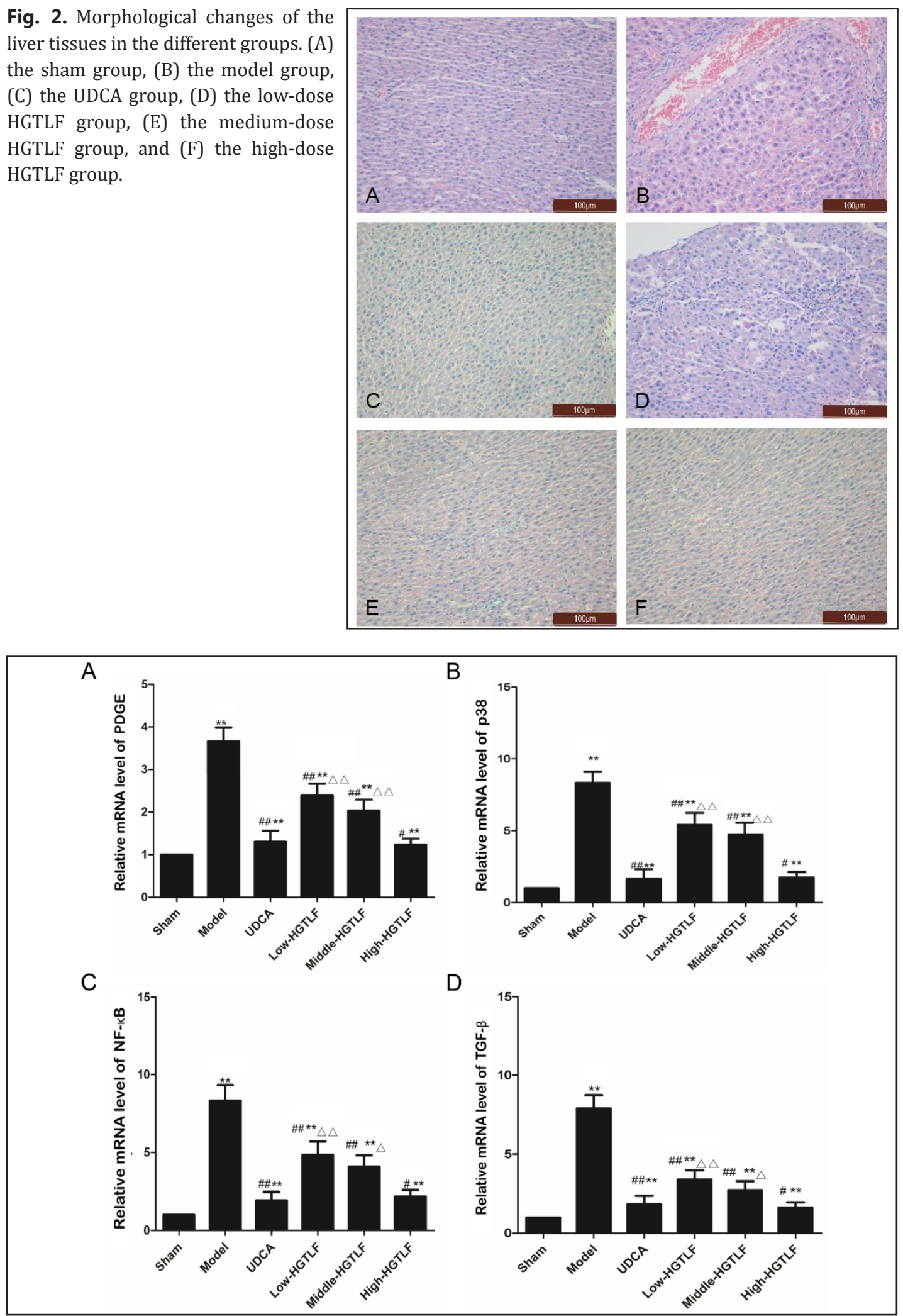

Fig. 3. Effects of HGTLF on hepatic fibrosis-related genes. (A) PDGF, (B) p38, (C) NF- $\mathrm{B}$, and (D) TGF- $\beta$. The data are presented as the mean $\pm \mathrm{SD}$. ${ }^{*} \mathrm{P}<0.05$ compared with the sham group; ${ }^{\#} \mathrm{P}<0.05$ compared with the model group; ${ }^{\triangle} \mathrm{P}<0.05$ compared with the UDCA group.

\section{KARGER}


A

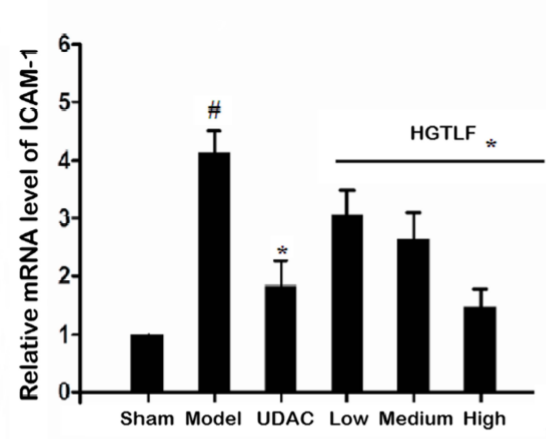

C

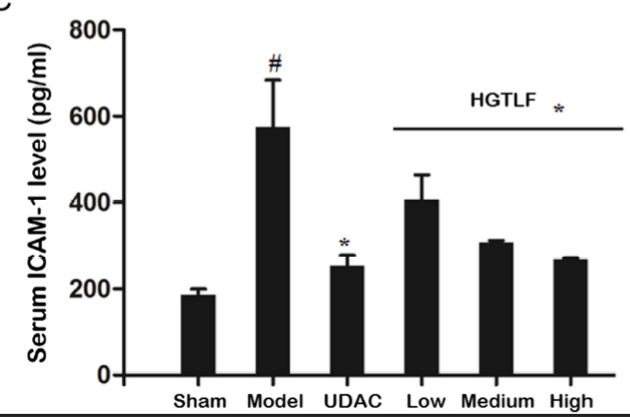

B

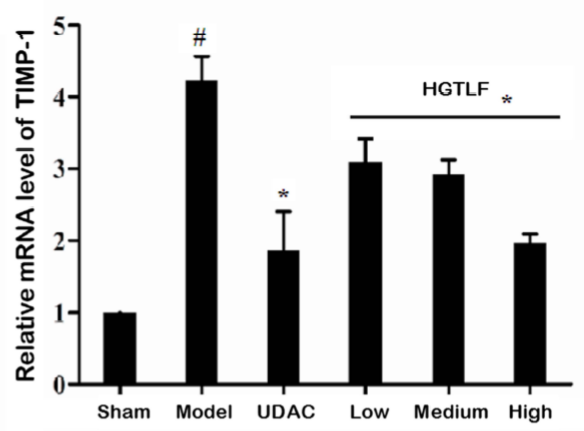

D

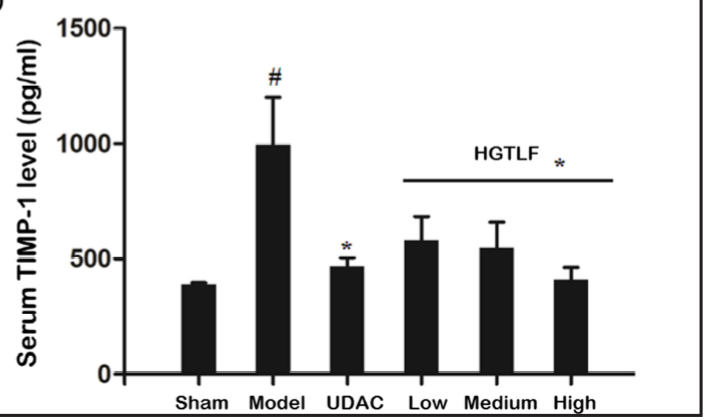

Fig. 4. Effect of HGTLF on ICAM-1 and TIMP-1 expression. The relative expression of ICAM-1 mRNA (A) and TIMP-1 mRNA (B) was determined by qRT-PCR. An ELISA assay was performed to detect serum levels of ICAM-1 (C) and TIMP-1 (D). The data are presented as the mean \pm SD. ${ }^{*} \mathrm{P}<0.05$ compared with the sham group; ${ }^{*} \mathrm{P}<0.05$ compared with the model group.

The HGTLF treatment inhibited the expression of hepatic fibrosis-related cellular events

Next, the possible involvement of hepatic fibrosis-related cellular events in anti-fibrosis process of HGTLF was examined. PDGF, which is commonly secreted by activated hepatic stellate cells, was down-regulated in response to the low, middle and high doses of HGTLF in comparison to that in the model group (Fig. 3A). As compared with the model group, all three doses of HFTLF resulted in down-regulation of both $\mathrm{p} 38$ and NF- $\kappa \mathrm{B}$, well-documented signaling pathways involved in hepatic fibrosis (Fig. 3B and 3C). In addition, all the doses of HGTFL significantly attenuated the expression of TGF- $\beta$, which serves as a pro-fibrosis factor (Fig. 3D). With regard to the aforementioned genes, the inhibitory action of HGTLF was strongest in the high-dose group.

\section{Potential biomarkers of HGTLF inhibition of anti-fibrosis}

All three doses of HGTLF decreased serum levels of ICAM-1 and TIMP-1, which are pivotal molecules in the regulation of the progression of hepatic fibrosis (Fig. 4C and 4D), as well as mRNA levels of ICAM-1 and TIMP-1 (Fig. 4 A and 4B).

\section{Discussion}

This study confirmed the anti-hepatic fibrotic effects of HGTLF in a mouse model of BC. The data suggested that all three doses of HGTLF effectively ameliorated hepatic fibrosis and inflammation inducted by biliary obstruction. Notably, the therapeutic effect of the highdose HGTLF treatment was the same as that of UDAC, a current anti-BC drug [11].

Blood biochemical indexes, which are related to liver function, are important indicators when evaluating the effects of $\mathrm{BC}$ therapy. For example, overexpressed inflammatory 
cytokines IL-8, IL-12 and TNF- $\alpha$ were involved in liver cell apoptosis [12]. Previous studies reported changes in serum activities of various enzymes (e.g., ALT, AST, GGT, and ALP) and serum levels of hepatic metabolism-related molecules (e.g., T-BIL and D-BIL) in liver injury $[13,14]$. In the present study, the enzymatic activities of ALT, AST, GGT, and ALP, in addition to the serum levels of T-BIL and D-BIL, were used to evaluate liver function in response to the HGTLF treatment. The serum enzymatic activity of ALT, AST, GGT, and ALP and the serum levels of T-BIL and D-BIL were lower in the mice with bile duct ligation, pointing to hepatic injury.

In the present study, the observation of inflammatory cell infiltration and fiber connective tissue hyperplasia pointed to the successful establishment of the BC model. Following the HGTLF treatment, both inflammatory cell infiltration and fiber connective tissue hyperplasia improved in all the groups, but the best therapeutic response was observed in the high-dose group. These data indicated that HGTLF exerted favorable effects on BC but that these effects ultimately depended on the dose.

Hepatic fibrosis represents a transition stage from bile duct blockage to $\mathrm{BC}$ [15]. Multiple biological processes, including inflammation and hepatic stellate cell proliferation and activation, regulate the pathogenesis of hepatic fibrosis [16]. The TGF- $\beta$ signaling pathway is closely associated with the development and progression of hepatic fibrosis [17]. Previous studies reported that bile duct blockage induced the synthesis and secretion of TGF- $\beta$ and that TGF- $\beta$ played a critical role in the activation of hepatic stellate cells and their transformation into fibroblast-like cells [18-21]. In the present study, as compared to the liver tissue in the model group, the level of TGF- $\beta$ mRNA was significantly down-regulated in the liver tissue of all the HGTLF groups, irrespective of the dose. This finding suggested that HGTLF might potentially inhibit hepatic stellate cell activation. This idea was further confirmed by HGTLFinduced down-regulation of PDGF, which is commonly secreted by activated hepatic stellate cells [22]. In addition, HGTLF suppressed the expression of PDGF mRNA, which promotes mitosis and has been shown to be involved in the activation of hepatic stellate cells [23]. These data suggested that HGTLF seemed to inhibit hepatic stellate cell activation in mice with bile duct ligation.

During hepatic fibrosis, the activation of hepatic stellate cells and subsequent interaction of these cells with immune cells, mediated by ICAM-1, result in a positive feedback circuit, which promotes the formation of hepatic fibrosis [24]. In the present study, following the development of hepatic fibrosis in the model mice, the serum levels and mRNA levels of ICAM1 increased. Moreover, HGTLF significantly attenuated the increases in ICAM-1 levels. These data support the idea that the HGTLF treatment improved hepatic fibrosis. The response of TIMP-1 to the HGTLF treatment was similar to that of ICAM-1. TIMP-1 is responsible for maintaining a balance between the synthesis and the degradation of the extracellular matrix $[25,26]$. It is also involved in inhibiting the activity of matrix metalloproteins [27]. In the present study, the inhibitory effect of HGTLF resulted in the release of matrix metalloproteins and degradation of the extracellular matrix, which was in accordance with the findings of

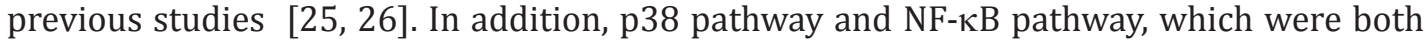
closely related to hepatic fibrosis, were also inhibited by HGTLF. As reported in previous studies, the involvement of p38 and NF- $\mathrm{BB}$ in hepatic fibrosis is linked to their regulatory role in inflammation and hepatic stellate cell activation [28, 29]. In the present study, the inhibition of p38 and NF- $\mathrm{KB}$ expression pointed to the alleviation of hepatic fibrosis.

\section{Conclusion}

The data showed that HGTLF plays an important role in inhibiting BC. The potential mechanism underlying the activity of HGTLF might be prevention of hepatic fibrosis via the regulation of hepatic fibrosis-related signals, such as PDGF, TGF- $\beta, \mathrm{p} 38, \mathrm{NF}-\kappa \mathrm{B}, \mathrm{ICAM}-1$, and TIMP-1. The results of the present study suggest that HGTLF might have value as a clinical treatment for $\mathrm{BC}$ in the future. 


\section{Cellular Physiology Cell Physiol Biochem 2017;44:368-376

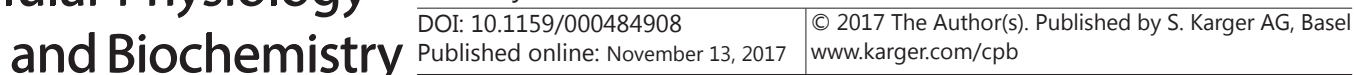 Xuan et al.: Effect of HGTLF on Biliary Cirrhosis}

\section{Acknowledgements}

This work was supported by National Natural Science Foundation of China (No.81373766), Youth Development Projects of Army Medical Technology (No.15QNP021), Medical and Health Research Projects of Army (No.15MS063) and Nanjing Science and Technology Project (No.201605061).

\section{Disclosure Statement}

No competing financial interests exist.

\section{References}

1 Nguyen DL, Juran BD, Lazaridis KN: Primary biliary cirrhosis. Best Pract Res Clin Gastroenterol 2010;24:647-654.

- Kottyan LC, Zoller EE, Bene J, Lu X, Kelly JA, Rupert AM, Lessard CJ, Vaughn SE, Marion M, Weirauch MT, Namjou B, Adler A, Rasmussen A, Glenn S, Montgomery CG, Hirschfield GM, Xie G, Coltescu C, Amos C, Li H, Ice JA, Nath SK, Mariette X, Bowman S, Registry UKPSsS, Rischmueller M, Lester S, Brun JG, Goransson LG, Harboe E, Omdal R, Cunninghame-Graham DS, Vyse T, Miceli-Richard C, Brennan MT, Lessard JA, Wahren-Herlenius M, Kvarnstrom M, Illei GG, Witte T, Jonsson R, Eriksson P, Nordmark G, Ng WF, Registry UKPSsS, Anaya JM, Rhodus NL, Segal BM, Merrill JT, James JA, Guthridge JM, Scofield RH, Alarcon-Riquelme M, Bae SC, Boackle SA, Criswell LA, Gilkeson G, Kamen DL, Jacob CO, Kimberly R, Brown E, Edberg J, Alarcon GS, Reveille JD, Vila LM, Petri M, Ramsey-Goldman R, Freedman BI, Niewold T, Stevens AM, Tsao BP, Ying J, Mayes MD, Gorlova OY, Wakeland W, Radstake T, Martin E, Martin J, Siminovitch K, Moser Sivils KL, Gaffney PM, Langefeld CD, Harley JB, Kaufman KM: The IRF5-TNP03 association with systemic lupus erythematosus has two components that other autoimmune disorders variably share. Hum Mol Genet 2015;24:582-596.

- Wang B, Sun MY, Long AH, Cao HY, Ren S, Bian YQ, Lu X, Gu HT, Liu CH, Liu P: Yin-Chen-Hao-Tang alleviates biliary obstructive cirrhosis in rats by inhibiting biliary epithelial cell proliferation and activation. Pharmacogn Mag 2015;11:417-425.

4 Lee TY, Chang HH, Chen JH, Hsueh ML, Kuo JJ: Herb medicine Yin-Chen-Hao-Tang ameliorates hepatic fibrosis in bile duct ligation rats. J Ethnopharmacol 2007;109:318-324.

5 Kobayashi H, Horikoshi K, Yamataka A, Lane GJ, Yamamoto M, Miyano T: Beneficial effect of a traditional herbal medicine (inchin-ko-to) in postoperative biliary atresia patients. Pediatr Surg Int 2001;17:386-389.

6 Li Z, Tian Y: To explore the regular pattern of HuaGanTongLuoFang. Acta Chinese Med Pharmacol 2014;5:47.

7 Tian Y, Xuan J, Cao P, Hu C, Cai X, Zhang W: The effect and mechanism of HuaGanTongLuoFang for antifibrosis of Primary Biliary Cirrhosis. Proceedings of the 25th National Conference on the Integration of Chinese and Western Medicine in the Digestive System of Diseases 2013:373.

$>8$ Trautwein C, Friedman SL, Schuppan D, Pinzani M: Hepatic fibrosis: Concept to treatment. J Hepatol 2015;62:S15-24.

-9 Schuppan D, Kim YO: Evolving therapies for liver fibrosis. J Clin Invest 2013;123:1887-1901.

10 Shen H, Sheng L, Chen Z, Jiang L, Su H, Yin L, Omary MB, Rui L: Mouse hepatocyte overexpression of NFkappaB-inducing kinase (NIK) triggers fatal macrophage-dependent liver injury and fibrosis. Hepatology 2014;60:2065-2076.

11 Liu F, Pan ZG, Ye J, Xu D, Guo H, Li GP, Xu KS, Hou XH, Song YH: Primary biliary cirrhosis-autoimmune hepatitis overlap syndrome: simplified criteria may be effective in the diagnosis in Chinese patients. J Dig Dis 2014;15:660-668.

12 Shao Y, Chen J, Zheng J, Liu CR: Effect of Histone Deacetylase HDAC3 on Cytokines IL-18, IL-12 and TNFalpha in Patients with Intrahepatic Cholestasis of Pregnancy. Cell Physiol Biochem 2017;42:1294-1302.

$\checkmark 13$ Liu XD, Wu JL, Liang J, Zhang T, Sheng QS: Globulin-platelet model predicts minimal fibrosis and cirrhosis in chronic hepatitis B virus infected patients. World J Gastroenterol 2012;18:2784-2792. 


\section{Cellular Physiology Cell Physiol Biochem 2017;44:368-376 \begin{tabular}{l|l|l} 
DOI: 10.1159/000484908 & $\begin{array}{l}\text { O 2017 The Author(s). Published by S. Karger AG, Basel } \\
\text { www.karger.com/cpb }\end{array}$
\end{tabular} \\ Xuan et al.: Effect of HGTLF on Biliary Cirrhosis}

14 Naoi S, Hayashi H, Inoue T, Tanikawa K, Igarashi K, Nagasaka H, Kage M, Takikawa H, Sugiyama Y, Inui A, Nagai T, Kusuhara H: Improved liver function and relieved pruritus after 4-phenylbutyrate therapy in a patient with progressive familial intrahepatic cholestasis type 2. J Pediatr 2014;164:1219-1227.

15 Gaskin KJ, Waters DL, Howman-Giles R, de Silva M, Earl JW, Martin HC, Kan AE, Brown JM, Dorney SF: Liver disease and common-bile-duct stenosis in cystic fibrosis. N Engl J Med 1988;318:340-346.

16 Wen YA, Liu D, Zhou QY, Huang SF, Luo P, Xiang Y, Sun S, Luo D, Dong YF, Zhang LP: Biliary intervention aggravates cholestatic liver injury, and induces hepatic inflammation, proliferation and fibrogenesis in BDL mice. Exp Toxicol Pathol 2011;63:277-284.

-17 Dooley S, ten Dijke P: TGF-beta in progression of liver disease. Cell Tissue Res 2012;347:245-256.

-18 Kelsaka E, Karakaya D, Sarihasan B, Baris S: Remifentanil pretreatment reduces myoclonus after etomidate. J Clin Anesth 2006;18:83-86.

19 Gressner OA, Lahme B, Demirci I, Gressner AM, Weiskirchen R: Differential effects of TGF-beta on connective tissue growth factor (CTGF/CCN2) expression in hepatic stellate cells and hepatocytes. J Hepatol 2007;47:699-710.

-20 Freise C, Heldwein S, Erben U, Hoyer J, Kohler R, Johrens K, Patsenker E, Ruehl M, Seehofer D, Stickel F, Somasundaram R: $\mathrm{K}(+)$-channel inhibition reduces portal perfusion pressure in fibrotic rats and fibrosis associated characteristics of hepatic stellate cells. Liver Int 2015;35:1244-1252.

21 Liu C, Chen X, Yang L, Kisseleva T, Brenner DA, Seki E: Transcriptional repression of the transforming growth factor beta (TGF-beta) Pseudoreceptor BMP and activin membrane-bound inhibitor (BAMBI) by Nuclear Factor kappaB (NF-kappaB) p50 enhances TGF-beta signaling in hepatic stellate cells. J Biol Chem 2014;289:7082-7091.

22 Borkham-Kamphorst E, Herrmann J, Stoll D, Treptau J, Gressner AM, Weiskirchen R: Dominant-negative soluble PDGF-beta receptor inhibits hepatic stellate cell activation and attenuates liver fibrosis. Lab Invest 2004;84:766-777.

23 Pinzani M: PDGF and signal transduction in hepatic stellate cells. Front Biosci 2002;7:d1720-1726.

-24 Rizk NM, Derbala MF: Genetic polymorphisms of ICAM 1 and IL28 as predictors of liver fibrosis severity and viral clearance in hepatitis C genotype 4. Clin Res Hepatol Gastroenterol 2013;37:262-268.

25 Achterberg VF, Buscemi L, Diekmann H, Smith-Clerc J, Schwengler H, Meister JJ, Wenck H, Gallinat S, Hinz B: The nano-scale mechanical properties of the extracellular matrix regulate dermal fibroblast function. J Invest Dermatol 2014;134:1862-1872.

26 Skotnicki JS, Zask A, Nelson FC, Albright JD, Levin JI: Design and synthetic considerations of matrix metalloproteinase inhibitors. Ann N Y Acad Sci 1999;878:61-72.

27 Hemmann S, Graf J, Roderfeld M, Roeb E: Expression of MMPs and TIMPs in liver fibrosis - a systematic review with special emphasis on anti-fibrotic strategies. J Hepatol 2007;46:955-975.

28 Luedde T, Schwabe RF: NF-kappaB in the liver--linking injury, fibrosis and hepatocellular carcinoma. Nat Rev Gastroenterol Hepatol 2011;8:108-118.

-29 Paik YH, Schwabe RF, Bataller R, Russo MP, Jobin C, Brenner DA: Toll-like receptor 4 mediates inflammatory signaling by bacterial lipopolysaccharide in human hepatic stellate cells. Hepatology 2003;37:1043-1055. 